\title{
An Evaluation of Urban Environmental Noise Pollution in Durres Municipality
}

\author{
MARSIDA KLEMO ${ }^{1}$, OSMAN METALLA ${ }^{2}$, AZEM HYSA $^{1}$, ELVIS CELA $^{3}$, \\ ABDULLA DIKU ${ }^{3}$, MIGENA NAKO ${ }^{3}$ \\ ${ }^{1}$ Applied and Natural Sciences Department, “Aleksander Moisiu” University, \\ Durres, ALBANIA \\ ${ }^{2}$ Marine and Engineering Science Department, “Aleksander Moisiu” University, \\ Durres, ALBANIA \\ ${ }^{3}$ Environmental Center for Protection, Education and Rehabilitation, \\ Tirana, ALBANIA
}

\begin{abstract}
Durres is the second most populous place on the Republic of Albania. This paper was focused in the evaluation of noise level at different areas of Durres Municipality which were categorized based on their activities like industrial, commercial and residential.

The main purpose of environmental noise monitoring was to assess the situation in Durres Municipality, to value the degree of impact on citizens and to create a database to better address the problems, in order to build an effective action plan to improve the situation in problem areas.

Monitoring has two basic objectives, such as: to protect us from noise that hinders and disrupts our daily activity and to protect us in the future from increasing noise levels that would bring concerns to people and quality of the environment.

To realize this study was used TESTO 816-1 supply that measures noise intensity level of a certain area. Measurements were carried out in different conditions of humidity and wind velocity, during morning and night time, from February 2019 to December 2020. Duration of each measurement was 15 min.

The results of this study revealed that the average equivalent noise level was: i) in the commercial area (during morning time $51.92 \mathrm{~dB}$, during night time $46.8 \mathrm{~dB}$ ), in the industrial area (during morning time $57.69 \mathrm{~dB}$, during night time $45.31 \mathrm{~dB}$ ) and in the residential area (during morning time $53.59 \mathrm{~dB}$, during night time 44.46 $\mathrm{dB})$.

As a conclusion it was evidenced that the noise levels for all the areas were over the permissible levels of $50 \mathrm{~dB}$ (during morning) and for commercial and industrial area were over $45 \mathrm{~dB}$ (during night). Also it was concluded that the consequences of these high levels cause moderate and serious annoyance for residents during the day and sleep disturbances (if windows are open) during the night.

This paper suggests some improvements to decrease side effects of noise pollution.
\end{abstract}

Key-Words: - Noise pollution, Average equivalent noise level $\left(\mathrm{L}_{\mathrm{eq}}\right)$, Maximum permissible noise level, Durres Municipality

Received: May 10, 2021. Revised: October 4, 2021. Accepted: October 14, 2021. October 20, 2021.

\section{Introduction}

In the main cities of Albania, noise continues to be a very disturbing phenomenon and with significant impacts on the health of residents of the most populated areas, including Durres.

For more than five years, the relevant state institutions have not measured noise parameters in any part of Durres Municipality. This has avoided facing the reality and further completely neglecting the noise pollution created. As a consequence this has led to a lack of coercive measures to improve the situation and protect the health of citizens
The World Health Organization (WHO) ranks noise pollution of the living environment as the second most hazardous factor impacting human health in

cities, after air pollution by PM10 and $\mathrm{PM}_{2.5}$ atmospheric aerosol particles $[1,2]$.

Noise pollution is a major problem in cities around the world [3]. Noise, an unwanted and irritating sound, is a form of environmental pollution and a source of stress. It can also be understood as a complex sound, a mixture of many different frequencies or notes not harmonically related [4]. 
It is more severe and widespread than ever before, and it will continue to increase in magnitude and severity because of population growth, urbanization, and the associated growth in the use of increasingly powerful, varied, and highly mobile sources of noise. It will also continue to grow because of sustained growth in highway, rail, and air traffic, which remain major sources of environmental noise $[3,5]$.

To be able to effectively deal with the problem of noise, there is a need to first identify the sources of noise. According to [6] the major sources of noise can be broadly divided into two: external and internal sources. However, [7] identified three categories of noise sources including:

a. Sources associated with activities and office equipment;

b. Sources associated with operation of building services;

c. Sources of environmental sound from outside the

building.

Continuous high level of noise can cause serious stress on the auditory and non-auditory, and nervous system of the city dwellers $[8,9]$. It is also leading cause of great annoyance for exposed population due to the poor conditions of engine, exhaust etc. [10].

There is a general agreement that exposure to sound levels less than $70 \mathrm{~dB}$ does not produce hearing damage, regardless of the duration of exposure. There is also general agreement that exposure for more than 8 hours to sound levels in excess of 85 $\mathrm{dB}$ is potentially hazardous; to place this in context, $85 \mathrm{~dB}$ is roughly equivalent to the noise of heavy truck traffic on a busy road. With sound levels above $85 \mathrm{~dB}$, damage is related to sound pressure (measured in $\mathrm{dB}$ ) and to time of exposure [3].

Various methodologies have been followed from the studies to monitor and analyze noise pollution. Among them we can mention the case of mobile measurement systems that are fully automated and consist of a transport vehicle and measurement station. The systems are also equipped with software [11].

Another way used to monitor noise are acoustic monitoring systems with the possibility of measurements without an operator. This system contains:

$\square$ One or several stations of monitoring - sound level meter, system of power supply, router etc.;

$\square$ Central module (device for analysis and storage of data);

$\square$ Channel of data transmission (GPRS/ADSL and Internet) [12].

\section{Materials and Methods}

In the framework of noise monitoring and the "Green lung" project, was undertaken this study to measure the noise level in Durres Municipality.

Environmental noise was monitored in full compliance with BE directive (2002/49/ EC directive) [13] on noise management in the environment. Data sets were measured using the sound level meter (TESTO 816-1) which is ideal for measuring noise intensity level in workplace, industrial environment, manufactures, public places etc. (fig 1).

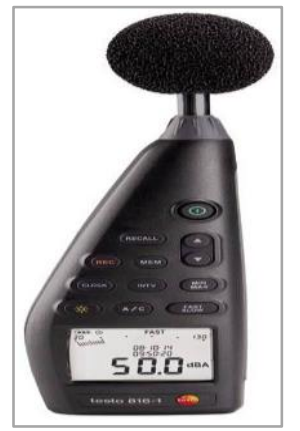

Fig. 1: Testo 816-1 supply

This device with which the measurements were performed can be classified in base of the characteristics such as:

- precise noise level measurements according to IEC 61672-1 Class 2 and ANSI S1.4 Type 2;

- ideal for health and safety inspections and emission control;

- PC software for data analysis and USB cable for data transfer.

The testo 816-1 is a sound level meter that can be used according to its instruction manual [14]. Here are some technical data:

\begin{tabular}{|c|c|}
\hline Accuracy \pm 1 digit & $\begin{array}{c} \pm 1.4 \mathrm{~dB} \\
\text { (under reference conditions: } 94 \\
\mathrm{~dB}, 1 \mathrm{kHz})\end{array}$ \\
\hline Measuring range & 30 to $130 \mathrm{~dB}$ \\
\hline Frequency range & $20 \mathrm{~Hz}$ to $8 \mathrm{kHz}$ \\
\hline Resolution & $0.1 \mathrm{~dB}$ \\
\hline $\begin{array}{c}\text { Frequency } \\
\text { weighting }\end{array}$ & $\mathrm{A} / \mathrm{C}$ \\
\hline Microphone & $1 / 2$ inch \\
\hline Measuring rate & $0.5 \mathrm{~s}$ \\
\hline Dynamic range & $100 \mathrm{~dB}$ \\
\hline Data storage & approx. 31000 measurements \\
\hline
\end{tabular}




\begin{tabular}{|c|c|}
\hline $\begin{array}{c}\text { Operating } \\
\text { temperature }\end{array}$ & 0 to $+40{ }^{\circ} \mathrm{C}$ \\
\hline $\begin{array}{c}\text { Storage } \\
\text { temperature }\end{array}$ & -10 to $+60{ }^{\circ} \mathrm{C}$ \\
\hline Battery type & $4 \times$ Type AA batteries \\
\hline Weight & $390 \mathrm{~g}$ \\
\hline Dimensions & $272 \times 83 \times 42 \mathrm{~mm}$ \\
\hline Time weighting & FAST $125 \mathrm{~ms} / \mathrm{SLOW} 1 \mathrm{sec}$ \\
\hline AC/DC output & $\begin{array}{c}\text { AC: } 1 \mathrm{VMS} \text { at full scale } / \mathrm{DC}: \\
10 \mathrm{mV} / \mathrm{dB}\end{array}$ \\
\hline
\end{tabular}

Noise level measurements were registered in $\mathrm{dB}$ (A) scale for 15 minutes in each place selected. Data registration were performed as follows:

- the date, time, place and duration of the monitoring were recorded;

- weather conditions were recorded including wind speed, cloud cover and humidity;

- The parameters monitored were $\mathrm{L}_{\mathrm{eq}}, \mathrm{L}_{\max }, \mathrm{L}_{\min }$.

The noise monitoring level was realized during morning time (6:00 am to $10.00 \mathrm{am})$ and night time $(10: 00 \mathrm{pm}$ to $6: 00 \mathrm{am})$ from February 2019 to December 2020.

A total of three areas were selected for this study. The areas were chosen taking into consideration traffic load, industrial and commercial activities, nearby institutions like hospital, judiciary, schools etc.

The monitoring areas as it is observed on the map 1 were:

- the commercial area (A)

- the industrial area (B)

- the residential area (C)

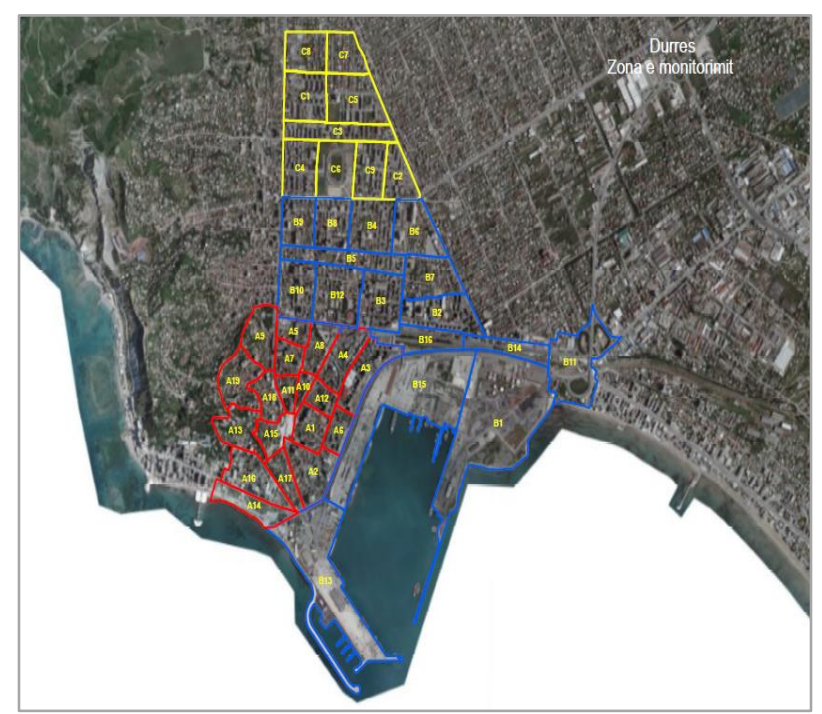

Fig. 1: Monitoring areas of Durres Municipality
Durrës is located on a flat plain between the river mouths of Erzen and Ishëm on the southeastern corner of the Adriatic Sea within the Mediterranean Sea.

The transport connections, concentration of economic institutions and industrial tradition underlie Durres' leading economic position in Albania. It is served by Durres port, one of the largest on the Adriatic Sea, which connects the city to other neighboring countries.

Its climate is considerably influenced by its proximity to the Adriatic Sea in the Mediterranean Sea and the mountains in the Western Lowlands in the hinterlands. The summers are predominantly hot and dry, the winters relatively mild, and falls and springs mainly stable, in terms of precipitation and temperatures.

According to the 2011 census, Durres Municipality had an estimated population of 113,249 of whom 56,511 were men and 56,738 women [15].

\section{Results and Discussion}

From the field measurements performed in the three monitored areas the following results were obtained (tab 1, tab 2, tab 3).

Table 1. $\mathrm{L}_{\mathrm{eq}}$ values for the commercial area (A)

\begin{tabular}{|c|c|c|}
\hline \multicolumn{3}{|c|}{ 19-Feb-19 } \\
\hline \multicolumn{2}{|c|}{ Sunny day / 84 \% humidity } \\
\hline $\begin{array}{c}\text { Number } \\
\text { of } \\
\text { monitori }\end{array}$ & $\begin{array}{c}\text { Leq } \\
\text { (dB } \text { )during } \\
\text { morning }\end{array}$ & $\begin{array}{c}\text { Leq (dB) } \\
\text { during } \\
\text { night }\end{array}$ \\
\hline A17-1 & 42.70 & 42.00 \\
\hline A17-2 & 51.55 & 45.40 \\
\hline A17-3 & 52.50 & 46.40 \\
\hline A17-4 & 53.90 & 47.40 \\
\hline A2-2 & 53.90 & 48.10 \\
\hline A17-5 & 53.90 & 48.10 \\
\hline A2-4 & 53.90 & 48.80 \\
\hline \multicolumn{3}{|c|}{$\mathbf{2 2 - F e b - 1 9}$} \\
\hline Sunny day / 77\% humidity \\
\hline A15-1 & 48.10 & 43.10 \\
\hline A15-2 & 47.90 & 45.10 \\
\hline A15-3 & 47.90 & 50.70 \\
\hline A1-1 & 47.90 & 63.50 \\
\hline A1-5 & 47.90 & 52.70 \\
\hline A2-5 & 54.80 & 48.10 \\
\hline A2-3 & 54.80 & 52.20 \\
\hline A2-6 & 53.50 & 51.00 \\
\hline A6-3 & 57.50 & 51.00 \\
\hline A1-2 & 57.30 & 44.30 \\
\hline
\end{tabular}

\subsection{Study Area}




\begin{tabular}{|c|c|c|}
\hline \multicolumn{3}{|c|}{ 17-May-19 } \\
\hline \multicolumn{3}{|c|}{$\begin{array}{c}\text { Sunny day / } 72 \% \text { humidity / } \\
\text { wind velocity } 0 \mathrm{~km} / \mathrm{h}\end{array}$} \\
\hline A4-1 & 50.70 & 41.90 \\
\hline A4-2 & 51.20 & 42.80 \\
\hline A4-3 & 50.50 & 45.40 \\
\hline A 12-3 & 44.10 & 40.60 \\
\hline A 10-1 & 46.20 & 48.60 \\
\hline A11-1 & 51.10 & 46.40 \\
\hline A 10-2 & 46.50 & 39.60 \\
\hline \multicolumn{3}{|c|}{ 18-Маy-19 } \\
\hline \multicolumn{3}{|c|}{$\begin{array}{c}\text { Sunny day / } 72 \% \text { humidity / } \\
\text { wind velocity } 0 \mathrm{~km} / \mathrm{h}\end{array}$} \\
\hline A3-1 & 51.70 & 49.90 \\
\hline A3-2 & 59.20 & 53.10 \\
\hline A3-3 & 59.20 & 55.80 \\
\hline A3-4 & 53.00 & 50.00 \\
\hline A6-2 & 52.50 & 49.70 \\
\hline A6-1 & 55.00 & 49.70 \\
\hline \multicolumn{3}{|c|}{ 23-Mar-19 } \\
\hline \multicolumn{3}{|c|}{$\begin{array}{c}\text { Sunny day / } 55 \% \text { humidity / } \\
\text { wind velocity } 0 \mathrm{~km} / \mathrm{h}\end{array}$} \\
\hline A5-4 & 50.20 & 52.90 \\
\hline A5-1 & 50.40 & 48.40 \\
\hline A5-3 & 49.20 & 40.70 \\
\hline A5-2 & 49.30 & 47.40 \\
\hline A5-5 & 49.20 & 49.40 \\
\hline \multicolumn{3}{|c|}{ 26-Mar-19 } \\
\hline \multicolumn{3}{|c|}{$\begin{array}{c}\text { Sunny day / } 72 \% \text { humidity / } \\
\text { wind velocity } 0 \mathrm{~km} / \mathrm{h}\end{array}$} \\
\hline A 8-1 & 47.50 & 45.40 \\
\hline A $8-2$ & 51.70 & 47.50 \\
\hline A $8-3$ & 50.10 & 47.90 \\
\hline \multicolumn{3}{|c|}{ 20-Se p-19 } \\
\hline \multicolumn{3}{|c|}{$\begin{array}{l}\text { Sunny day / } 68 \% \text { humidity } \\
\text { / wind velocity }<3 \mathrm{~km} / \mathrm{h}\end{array}$} \\
\hline A 14-1 & 45.55 & 40.70 \\
\hline A14-2 & 50.50 & 43.60 \\
\hline A 14-3 & 53.30 & 46.40 \\
\hline A 16-2 & 51.00 & 43.60 \\
\hline A 16-3 & 53.30 & 47.50 \\
\hline A 16-4 & 56.90 & 48.90 \\
\hline A 13-1 & 47.40 & 41.30 \\
\hline A 13-2 & 54.20 & 46.60 \\
\hline A 13-3 & 50.06 & 43.80 \\
\hline \multicolumn{3}{|c|}{ 21-Sep-19 } \\
\hline \multicolumn{3}{|c|}{$\begin{array}{l}\text { Sunny day / } 63 \% \text { humidity } \\
\text { /wind velocity }<2.8 \mathrm{~km} / \mathrm{h}\end{array}$} \\
\hline A 19-1 & 50.70 & 41.80 \\
\hline A18-1 & 51.90 & 42.10 \\
\hline A 18-2 & 49.80 & 39.80 \\
\hline A18-3 & 55.90 & 45.30 \\
\hline
\end{tabular}

Table 2. $\mathrm{L}_{\mathrm{eq}}$ values for the commercial area (B)

\begin{tabular}{|c|c|c|}
\hline \multicolumn{3}{|c|}{$31-J u l-20$} \\
\hline \multicolumn{3}{|c|}{$\begin{array}{c}\text { Sunny day/ } 62 \% \text { humidity / } \\
\text { wind velocity }<3 \mathrm{~km} / \mathrm{h}\end{array}$} \\
\hline $\begin{array}{c}\text { Number of } \\
\text { monitoring } \\
\text { station }\end{array}$ & $\begin{array}{l}\text { Leq (dB) } \\
\text { during } \\
\text { morning }\end{array}$ & $\begin{array}{c}\text { Leq } \\
\text { (dB) } \\
\text { during } \\
\text { night }\end{array}$ \\
\hline B1-1 & 57.40 & 41.60 \\
\hline B 1-2 & 63.80 & 48.80 \\
\hline B2-1 & 55.30 & 41.30 \\
\hline B2-2 & 60.20 & 48.40 \\
\hline B2-3 & 49.20 & 40.60 \\
\hline \multicolumn{3}{|c|}{ 7-Aug-20 } \\
\hline \multicolumn{3}{|c|}{$\begin{array}{c}\text { Sunny day/ } 67 \% \text { humidity / } \\
\text { wind velocity }<3 \mathrm{~km} / \mathrm{h}\end{array}$} \\
\hline B3-1 & 44.90 & 41.10 \\
\hline B3-2 & 63.20 & 52.10 \\
\hline B4-1 & 51.80 & 42.50 \\
\hline B4-2 & 46.50 & 38.10 \\
\hline B6-1 & 57.20 & 49.40 \\
\hline B6-2 & 55.00 & 43.10 \\
\hline B6-3 & 48.00 & 41.80 \\
\hline \multicolumn{3}{|c|}{ 17-Aug-20 } \\
\hline \multicolumn{3}{|c|}{$\begin{array}{c}\text { Sunny day / } 61 \% \text { humidity / } \\
\text { wind velocity }<3 \mathrm{~km} / \mathrm{h}\end{array}$} \\
\hline B5-1 & 49.20 & 39.30 \\
\hline B5-2 & 49.70 & 40.70 \\
\hline B5-3 & 48.20 & 43.80 \\
\hline B5-4 & 46.80 & 41.90 \\
\hline B5-5 & 52.50 & 46.90 \\
\hline B7-1 & 50.00 & 40.10 \\
\hline B7-2 & 53.60 & 48.70 \\
\hline B7-3 & 54.30 & 45.90 \\
\hline \multicolumn{3}{|c|}{ 18-Aug-20 } \\
\hline \multicolumn{3}{|c|}{$\begin{array}{c}\text { Sunny day / } 62 \% \text { humidity / } \\
\text { wind velocity }<3 \mathrm{~km} / \mathrm{h}\end{array}$} \\
\hline B8-1 & 53.50 & 43.50 \\
\hline B8-2 & 49.30 & 39.20 \\
\hline B9-1 & 57.70 & 51.70 \\
\hline B9-2 & 52.60 & 42.40 \\
\hline B9-3 & 47.10 & 40.10 \\
\hline \multicolumn{3}{|c|}{ 19-Aug-20 } \\
\hline \multicolumn{3}{|c|}{$\begin{array}{c}\text { Sunny day / } 69 \% \text { humidity / } \\
\text { wind velocity }<3 \mathrm{~km} / \mathrm{h}\end{array}$} \\
\hline B 10-1 & 52.80 & 49.60 \\
\hline B 10-2 & 45.30 & 43.20 \\
\hline B10-3 & 55.60 & 48.50 \\
\hline B12-1 & 48.80 & 41.70 \\
\hline B 12-2 & 63.10 & 58.10 \\
\hline \multicolumn{3}{|c|}{ 24-Aug-20 } \\
\hline \multicolumn{3}{|c|}{$\begin{array}{c}\text { Sunny day/ } 63 \% \text { humidity / } \\
\text { wind velocity }<3 \mathrm{~km} / \mathrm{h}\end{array}$} \\
\hline B 11-1 & 56.80 & 46.90 \\
\hline B11-2 & 54.50 & 44.50 \\
\hline B 11-3 & 56.20 & 47.55 \\
\hline B 11-4 & 57.10 & 50.00 \\
\hline B 13-1 & 56.00 & 47.20 \\
\hline B 13-2 & 52.00 & 42.60 \\
\hline B 13-3 & 54.30 & 40.20 \\
\hline B 13-4 & 54.80 & 41.40 \\
\hline B 13-5 & 58.00 & 49.00 \\
\hline B 14-1 & 59.20 & 45.30 \\
\hline B 14-2 & 53.30 & 42.50 \\
\hline \multicolumn{3}{|c|}{$11-$ Se p-20 } \\
\hline \multicolumn{3}{|c|}{$\begin{array}{c}\text { Sunny day / } 68 \% \text { humidity / } \\
\text { wind velocity }<3 \mathrm{~km} / \mathrm{h}\end{array}$} \\
\hline B 15-1 & 61.20 & 49.70 \\
\hline B 15-2 & 61.70 & 47.30 \\
\hline B 16-1 & 55.50 & 45.20 \\
\hline
\end{tabular}


Table 3. $\mathrm{L}_{\mathrm{eq}}$ values for the commercial area $(\mathrm{C})$

\begin{tabular}{|c|c|c|}
\hline \multicolumn{3}{|c|}{ 9-Oct-20 } \\
\hline $\begin{array}{c}\text { Sunny day / } 58 \% \text { humidity / } \\
\text { velocity } \text { wind < } 4 \mathbf{k m} / \mathbf{h}\end{array}$ \\
\hline $\begin{array}{c}\text { Number of } \\
\text { monitoring } \\
\text { station }\end{array}$ & $\begin{array}{c}\text { Leq (dB) } \\
\text { during } \\
\text { morning }\end{array}$ & $\begin{array}{c}\text { Leq } \\
\text { (dB ) } \\
\text { during } \\
\text { night }\end{array}$ \\
\hline C1-1 & 57.60 & 48.00 \\
\hline C1-2 & 53.30 & 44.30 \\
\hline \multicolumn{3}{|c|}{ 14-Oct-20 } \\
\hline $\begin{array}{c}\text { Sunny day / 60 \% humidity / } \\
\text { velocity wind < 3.2 km/h }\end{array}$ \\
\hline C2-1 & 58.80 & 48.90 \\
\hline C2-2 & 57.40 & 45.90 \\
\hline C2-3 & 51.00 & 41.10 \\
\hline \multicolumn{3}{|c|}{ 19-Nov-20 } \\
\hline
\end{tabular}

Sunny day/ $62 \%$ humidity / velocity wind $<3 \mathrm{~km} / \mathrm{h}$

\begin{tabular}{|r|r|r|}
\hline C3-1 & 57.50 & 45.20 \\
\hline C3-2 & 52.80 & 42.20 \\
\hline C3-3 & 54.70 & 48.20 \\
\hline \multicolumn{3}{|c|}{ 24-Nov-20 } \\
\hline
\end{tabular}

Sunny day/ $66 \%$ humidity / velocity wind $<3 \mathrm{~km} / \mathrm{h}$

\begin{tabular}{|c|c|c|}
\hline C4-1 & 59.60 & 46.40 \\
\hline C4-2 & 52.60 & 42.20 \\
\hline C4-3 & 53.80 & 40.10 \\
\hline C4-4 & 56.50 & 44.60 \\
\hline C4-5 & 50.70 & 39.40 \\
\hline \multicolumn{3}{|c|}{ 23-Nov-20 } \\
\hline \multicolumn{3}{|c|}{$\begin{array}{c}\text { Sunny day/ } 67 \% \text { humidity / } \\
\text { velocity wind }<3.5 \mathrm{~km} / \mathrm{h}\end{array}$} \\
\hline C5-1 & 56.90 & 43.90 \\
\hline C5-2 & 49.90 & 39.70 \\
\hline \multicolumn{3}{|c|}{ 6-Dec-20 } \\
\hline \multicolumn{3}{|c|}{$\begin{array}{c}\text { Sunny day/ } 62 \% \text { humidity / } \\
\text { velocity wind }<3.1 \mathrm{~km} / \mathrm{h}\end{array}$} \\
\hline C6-1 & 58.60 & 47.80 \\
\hline C6-2 & 52.80 & 45.10 \\
\hline C6-3 & 50.40 & 41.70 \\
\hline
\end{tabular}

Sunny day/ $67 \%$ humidity / velocity wind $<3 \mathbf{~ k m} / \mathbf{h}$

\begin{tabular}{|r|r|r|}
\hline C7-1 & 59.70 & 50.70 \\
\hline C7-2 & 52.10 & 41.60 \\
\hline \multicolumn{3}{|c|}{ 17-Dec-20 } \\
\hline \multicolumn{3}{|c|}{} \\
\hline
\end{tabular}

\begin{tabular}{|c|c|c|}
\hline \multicolumn{3}{|c|}{$\begin{array}{c}\text { Sunny day/ } 62 \% \text { humidity / } \\
\text { velocity wind }<3 \mathrm{~km} / \mathrm{h}\end{array}$} \\
\hline C8-1 & 55.50 & 43.90 \\
\hline $\mathrm{C} 8-2$ & 52.60 & 40.70 \\
\hline $\mathrm{C} 8-3$ & 50.40 & 44.30 \\
\hline
\end{tabular}

Sunny day/ $63 \%$ humidity / velocity wind $<3 \mathrm{~km} / \mathrm{h}$

\begin{tabular}{|l|l|l|}
\hline C9-1 & 56.80 & 46.40 \\
\hline C9-2 & 49.30 & 39.70 \\
\hline
\end{tabular}

In table 4 and table 5 are respectively shown the average equivalent noise levels and the maximum permissible values $[16,17]$.

Table 4. $<\mathrm{L}_{\text {eq }}>$ for the three study areas

\begin{tabular}{|lcc|}
\hline \multicolumn{1}{|c}{ Area } & $\left\langle\mathbf{L}_{\mathrm{eq}}>\mathbf{( d B )}\right.$ & $\left\langle\mathbf{L}_{\mathrm{eq}}>(\mathbf{d B})\right.$ \\
& During morning & During night \\
& & \\
\hline Commercial & 51.92 & 46.8 \\
Industrial & 57.69 & 45.31 \\
Residential & 53.59 & 44.46 \\
\hline
\end{tabular}

Table 5. The maximum permissible levels of $\mathrm{L}_{\mathrm{eq}}$

\begin{tabular}{|cccc|}
\hline $\begin{array}{c}\mathbf{L}_{\text {eq }} \\
\text { for } \\
\text { outdoor } \\
\text { living } \\
\text { area } \\
\text { (dB) }\end{array}$ & $\begin{array}{c}\text { Critical } \\
\text { heath } \\
\text { effect }\end{array}$ & $\begin{array}{c}\mathbf{L}_{\text {eq }} \\
\text { for } \\
\text { outside } \\
\text { bedrooms } \\
\text { (dB) }\end{array}$ & $\begin{array}{c}\text { Critical } \\
\text { health } \\
\text { effect }\end{array}$ \\
\hline & $\begin{array}{c}\text { Moderate } \\
\text { annoyance } \\
\text { daytime } \\
\text { and evening }\end{array}$ & & $\begin{array}{c}\text { Sleep } \\
\text { disturbance, } \\
\text { (windows } \\
\text { open) }\end{array}$ \\
& $\begin{array}{c}\text { Serious } \\
\text { annoyance } \\
\text { daytime } \\
\text { and evening }\end{array}$ & & \\
\hline
\end{tabular}

Referring to the results in table 4 and standards in table 5 :

- in the commercial area during morning time the average equivalent noise level was $51.92 \mathrm{~dB}$.

This can cause moderate annoyance in everyday

people activities;

- in the commercial area during night time the average equivalent noise level was $46.8 \mathrm{~dB}$. This can cause sleep disturbance (if windows are open) for residents in that zone;

- in the industrial area during morning time the average equivalent noise level was $57.69 \mathrm{~dB}$ and

this can cause serious annoyance in everyday people activities;

- in the industrial area during night time the average equivalent noise level was $45.31 \mathrm{~dB}$. This can cause sleep disturbance (if windows are open) for residents near this area;

- in the residential area during morning time the average equivalent noise level was $53.59 \mathrm{~dB}$ and this can cause moderate annoyance for 
residents and in everyday people activities in that area;

- in the residential area during night time the average equivalent noise level was $44.46 \mathrm{~dB}$ and there isn't any annoyance for residents.

Measurements performed for each area were used to plot also the following graphs (Fig.2).

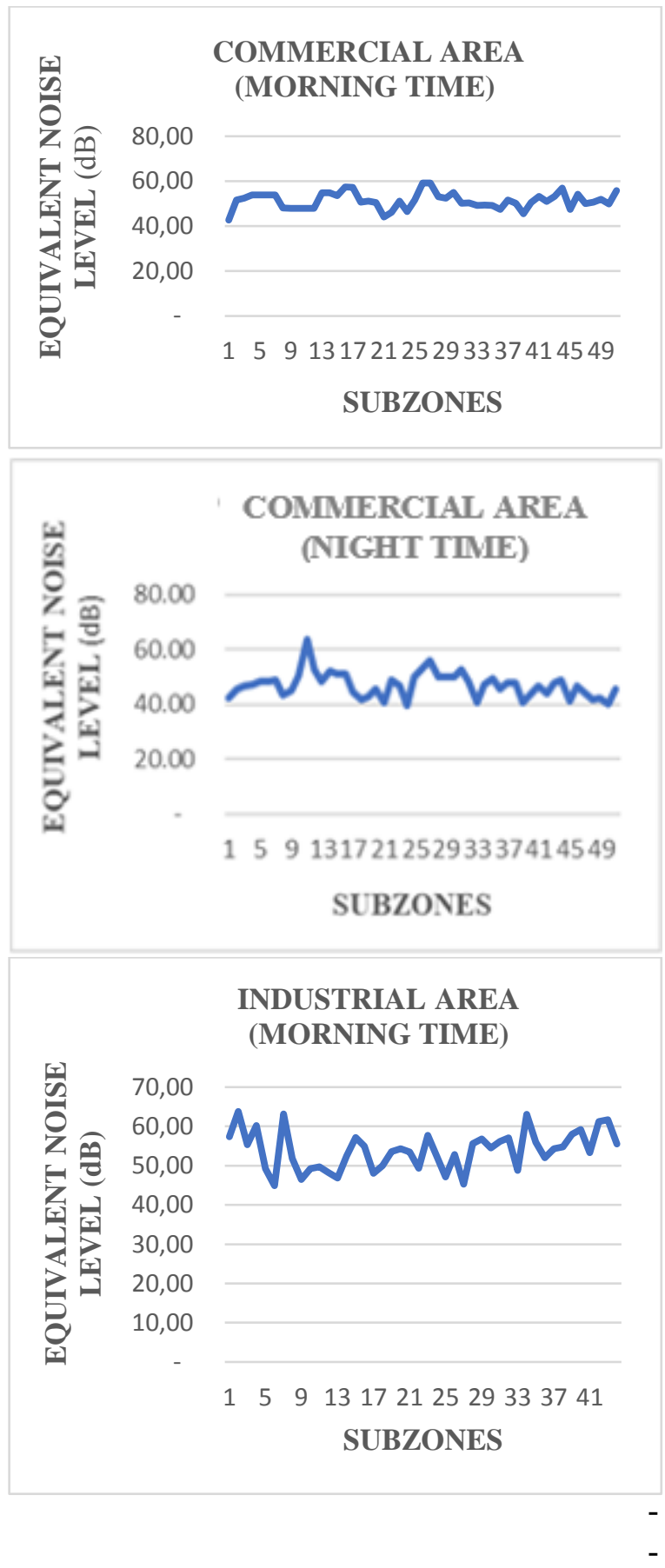

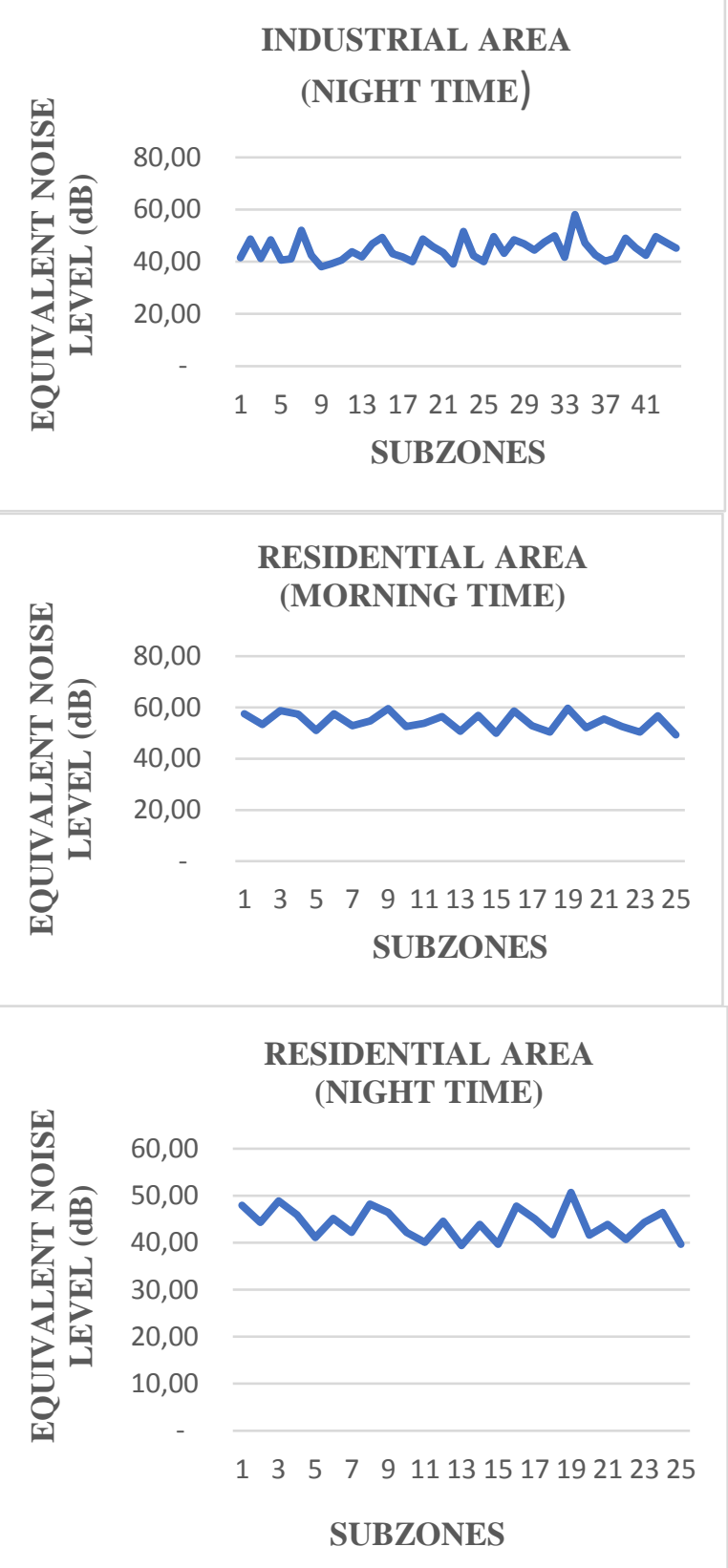

Fig. 2: Equivalent noise levels during morning and night time for different subzones in industrial, commercial and residentials areas of Durres Municipality

From the presentation of the graphs and the tabular data it was noticed that the areas with the most problems with the noise level were:

- in the commercial subzones: A3-2 and A3-3

(near Durres port) with the highest value $59.2 \mathrm{~dB}$ (during the morning) and A1-1 (in the city center) with the highest value $63.5 \mathrm{~dB}$ (during the night);

- in the industrial subzones: B1-2 (inside Durres Port) with the highest value $63.8 \mathrm{~dB}$ (during the morning) and B12-2 (sports palace "Ramazan Njala") with the highest value $58.1 \mathrm{~dB}$ (during the night) ; 
- in the residential subzone C7-1 (between Dardania street and King Pirro street) with the highest values $59.7 \mathrm{~dB}$ (during the morning) and $50.7 \mathrm{~dB}$ (during the night).

- As a result of these findings, we can say that the highest level of noise during the morning is in the subzone B1-2 (inside Durres port) with $63.8 \mathrm{~dB}$ and during the night in the subzone A1-1 (in the city center) with $63.5 \mathrm{~dB}$

\section{Conclusions}

This study shows an important information for the noise exposure to Durres Municipality residents.

As we can see from the graphic results, the highest values of noise were located in areas such as Durres port or near it, in the city center or suburban streets with traffic and more businesses nearby.

The highest value of noise during the morning was identified in Durres port with $63.8 \mathrm{~dB}$. This was due to the daily activity of working with containers, discharges, transport of goods, work of cranes, etc.

The highest value of noise during the night was identified around city center with $63.5 \mathrm{~dB}$. This was due to the great mobility that this area had both from cars and the activity of bars concentrated there.

It was identified that the average equivalent noise levels in the monitoring areas can cause sleep disturbance, moderate and serious annoyance to people living near commercial, industrial and residentials sites.

From what was mentioned above we can say that sources of noise pollution in Durres Municipality in general are:

- traffic of vehicles, rail, sea;

- poor condition of vehicles;

- poor condition of roads in urban areas;

- lack of secondary roads which can make possible to reduce traffic;

- construction industry;

- overcrowding from tourism;

The novelty that this paper brings is that:

- there is no study so far to monitor the noise level in Durres Municipality;

- this paper provides information on the noise level in most of the areas of Durres Municipality and addresses the hottest points and the highest level of pollution;

- The data extracted from this study will serve the relevant institutions to correctly manage the noise levels in the environment

In conclusion we can say that :
- it should be raised population awareness of changing habits to use alternative transport;

- competent structures have to take action and implement plans in order to ensure the health and safety of the inhabitants of Durres Municipality

\section{References:}

[1] Lozhkina O, Lozhkin V, Vorontsov I, Druzhinin P (2020) : Evaluation of extreme traffic noise as hazardous living environment factor in Saint Petersburg, Transportation research procedia 50, pg 389-396

[2] World Health Organization, 2020. Guidelines for Community Noise. Available at: https://www.who.int/docstore/peh/noise/guideli nes2.html (accessed 07 June 2020)

[3] Hiral J. Jariwala, Huma S. Syed, Minarva J. Pandya, Yogesh M. Gajera (March 2017): "Noise Pollution \& Human Health: A Review", Conference on Noise and Air Pollution: Challenges and Opportunities.

[4] Ganiyu, S. A. and Adedeji, Y. M. D (July 2011): A study of the sources of noise pollution and their impacts on the built environment, Conference: West Africa Built Environment Research (WABER) Conference, At Accra, Ghana.

[5] Odat S (2015) : Noise pollution in Irbid cityJordan, Fluctuation and noise letters, vol 14, No.4, 1550037, World Scientific Publishing Company

DOI: $10.1142 / \mathrm{S} 0219477515500376$.

[6] Ogunsote, O. O. (1991): Introduction to Building Climatology - A Basic Course for Architecture Students, Zaria: Ahmadu Bello University Press Limited

[7] Gregory, C. T. (1998). "Building Noise Control Applications" in Architectural Acoustics. Edited by William J. C. and Joseph A. W. pp. $100-150$

[8] Alam, J.B., Jobair.J. Rahman.M.M, Dikshit. A.K. and Khan S.K. (2006) : Study on traffic noise level of sylhet by multiple regression analysis associated with health hazards $\|$, Iran. J.Environ. Health. Sci.Eng; 3(2):71-78.

[9] Murthy,V.K., Khanal, S.N. (2007) : Assessment of traffic noise pollution in Banepa, a semi urban town of Nepal, Kathmandu university,Journal of science, engineering and technology;1:1-9.

[10] Baaj,M.H., El-Fadel.M., Shazbak.S.M. and Saliby.E. (2001): Modeling noise at elevated highways in urban areas: a practical 
application, Journal of Urban Planning and Development, 2001;127 (4):169-180.

[11] Malec A, Borowski G (2018): Monitoring of road noise in the urban environment of Lublin, Journal of Ecological Engineering, vol 19, Issue 4, pg 159-166, ISSN 22998993

[12] Vasilyev A. V (2017) : New methods and approaches to acoustic monitoring and noise mapping of urban territories and experience of it approbation in conditions of Samara region of Russia, Procedia engineering 176, pg 669 674 or available online www.elsevier.com/locate/procedia

[13]https://eur-lex.europa.eu/legalcontent/EN/TXT/?uri=CELEX:32002L0049

[14]https://staticint.testo.com/media/45/02/591a3be 05985/testo-816-1-Instruction-Manual.pdf

[15] Durrës - Wikipedia

[16] Charan P.D (2017) : An assessment of environmental noise pollution in Bikaner city of western Rajasthan, India, IJLST, 10 (3) : 33 $-37$

[17] Comnoise-4.PDF (who.int)

\section{Contribution of Individual Authors to the Creation of a Scientific Article (Ghostwriting Policy)}

Migena Nako, Elvis Cela, Abdulla Diku have collected data in the field and have done processing and construction of data

Osman Metalla, Marsida Klemo, Azem Hysa have interpreted and evaluated the data

\section{Creative Commons Attribution License 4.0} (Attribution 4.0 International, CC BY 4.0)

This article is published under the terms of the Creative Commons Attribution License 4.0

https://creativecommons.org/licenses/by/4.0/deed.e $\underline{\mathrm{n} \text { US }}$ 